\title{
Comparative Assessment of the Nutritional Fitness of Wild and Cultured African Catfish (Clarias gariepinus)
}

\author{
Ayandiran Tolulope Akinpelu ${ }^{1}$, Ogundiran Mathew Akinloye ${ }^{1^{*}}$ \\ Ajala Olasunmbo Olumuyiwa ${ }^{1}$, Opasola Olaniyi Afolabi ${ }^{2}$ \\ and Olanipekun Abimbola Stephen ${ }^{1}$
}

\footnotetext{
${ }^{1}$ Environmental Biology Unit, Department of Pure and Applied Biology, Ladoke Akintola University of Technology, P.M.B. 4000, Ogbomoso, Nigeria. ${ }^{2}$ Department of Environmental Management and Toxicology, Kwara State University, Malete, Nigeria.
}

\section{Authors' contributions}

This work was carried out in collaboration among all authors. Author ATA designed the work. Author OMA wrote all the protocol, performed the statistical analysis and the first draft of the manuscript.

Author AOO managed the analysis of the work including proof reading of the manuscript draft while authors OOA and OAS managed the literature searches and other logistics. All authors read and approved the final manuscript.

\section{Article Information}

DOI: $10.9734 / A R R B / 2021 /$ v36i230345

Editor(s):

(1) Prof. Jean-Marie Exbrayat Université Catholique de Lyon, France. (2) Prof. Xiao-Xin Yan Department of Anatomy \& Neurobiology Central South University Xiangya School of Medicine, Changsha, Hunan, China.

(3) Dr. Bechan Sharma Department of Biochemistry, University of Allahabad, Allahabad, India. Reviewers:

(1) Mohamed EL. Sayed Megahed, National Institute of Oceanography and Fisheries, Egypt. (2) Önder Yildirim, Mugla Sitki Kocman University, Turkey. Complete Peer review History: http://www.sdiarticle4.com/review-history/51137

Original Research Article

Received 30 June 2019 Accepted 05 September 2019 Published 27 March 2021

\section{ABSTRACT}

The nutritional qualities of wild and cultured Clarias gariepinus from Oba Reservoir, Ikose, Ogbomoso, Oyo State, Nigeria, and the cultured fish from the Department of Fisheries and Aquaculture, Oyo State Ministry of Agriculture and Mineral Resources, Ogbomoso, Oyo State, Nigeria, were evaluated. The proximate composition, mineral element composition and essential amino acids profile of the sampled fish species were evaluated using standard laboratory procedures. The results of the proximate composition was observed to be high in cultured 
population compared to the Wild and there was a statistical significant difference in the amount of crude protein, fibres, carbohydrate, fat/lipid, ash and moisture contents across the two sampled populations (Wild; $17.94 \pm 0.19$, Cultured; $21.06 \pm 0.51$ ), $\mathrm{t}=-5.738, \mathrm{p}$-value $=0.001$. Mineral element content showed maximum amount of copper $(\mathrm{Cu})$, Lead $(\mathrm{Pb})$, Manganese $(\mathrm{Mn})$ and Iron $(\mathrm{Fe})$ in Wild population than in their cultured counterpart while the amount of Cadmium $(\mathrm{Cd})$ and Nickel ( $\mathrm{Ni}$ ) observed in Wild population were undetected. It was also discovered that all amino acid analysed were found to be higher in the cultured group compared to the wild. There were varied levels of significant correlations among all the measured amino acids contents across the two sampled populations. This study showed that the proximate composition, elemental contents and amino acids profiles of both the cultured and wild fishes varies significantly and the results proofed that the cultured fish sample were more nutritious than the wild population, therefore, good monitoring system of Oba Reservoir should be encouraged with strict vigilance.

Keywords: Proximate composition; mineral elements; amino acids; reservoir; catfish.

\section{INTRODUCTION}

Fish protein is a good source of high quality protein containing essential amino acids in the amount and proportion required for good nutrition and metabolic demand. It alsoprovides a good source of vitamins andminerals. Fish is a highly proteinous food consumed by a larger percentage of populace because of its availability and palatability [1]. Also, when compared to other protein sources like goat and chicken meat, it is safer, healthier and also known to be an excellent source of protein from amino acid composition and protein digestibility (Mikan et al., 2004). Fish is also one of the main sources of protein in the developing countries [2]. The flesh of oil-rich fish, such as herring, mackerel and catfish are important sources of the long chain n3 polyunsaturated fatty acids (PUFA) including eicosapentaenoic acid (EPA) and docosahexaenoic acid (DHA), due to the large amounts of these fatty acids in marine algae upon which the fish feed [3]. However, the fat composition of fish is highly susceptible to various factors such as the time of year and the type of feed available (Effiong and Mohammed, 2008). Clarias gariepinus is a popular species in tropical aquaculture. It is widely distributed and accepted by many farmers in Africa because of its fast growth, large size, low bone content, hardiness, high yield, tolerance to poor water quality, omnivorous feeding habit, fine flavour, adaptability to overcrowding and high market value [4].

The measurement of proximate composition is often necessary to ensure that they meet the requirements of food regulations and commercial specifications [5]. Mineral elements are basic requirement of all living organisms. Some essential minerals may be toxic at their high concentration in body of animals [6]. Fish is an indispensable source of micronutrients, such as iron, iodine, zinc, vitamin $A$ and $B$ [7]. To compare the chemical composition of farmed fish with their natural counterparts is complex; study should be emphasized with more specialized geographical influence with diet playing an important role [8]. Farmed fish tend to be deficient in body protein and ash, so that they almost always contain more lipid than do wild fish, such lipid being the more saturated. Additionally, consumption of fish by humans has being recommended for its role in prevention of heart diseases $[9,10]$. Also, fish farming offers an alternative solution to the increasing demand for fish and its protein $[11,12,13]$. This study was designed to evaluate the nutritional contents of farmed and wild species of Clarias gariepinus.

\section{MATERIALS AND METHODS}

\subsection{Collection and Preparation of Samples}

Wild Clarias gariepinus were purchased from fishermen at Oba Reservoir, Ikose, Ogbomoso, Oyo State, Nigeria, while the cultured fish used were purchased from the Department of Fisheries and Aquaculture, Oyo State Ministry of Agriculture and Mineral Resources, Ogbomoso, Oyo State, Nigeria. The procured samples were moved to the fisheries Laboratory of the Department of Pure and Applied Biology, Ladoke Akintola University of Technology, Ogbomoso.

\subsection{Proximate Analysis}

The moisture contents of the fishes were determined before freeze-drying the samples. This was done using a forced air oven at $105^{\circ} \mathrm{C}$ 
first for five hours and then repeated for 30 minutes interval until a constant weight was obtained. The loss in weight was calculated as the moisture content [14]. Fat was quantified using the procedure of [14] with n-hexane $\left(68.5^{\circ} \mathrm{C}-69.1^{\circ} \mathrm{C}\right)$ as solvent. The protein content of each fish was assayed by the micro-Kjeldahl method as reported by Kirk and Sawyer [15]. The gram of nitrogen obtained was multiplied by the factor of 6.25 to obtain the protein content of each fish sample. The ash content of respective sample was determined by dry-ashing the

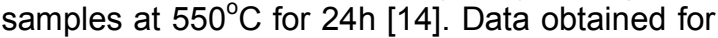
protein, ash and fat were corrected for moisture and presented on wet weight basis.

\subsection{Mineral Analyzes}

Selected minerals which include Copper, Zinc, Calcium, Magnesium, Potassium, Sodium, Phosphorus, Nitrogen, Iron and Selenium were determined using Atomic Absorption Spectrophotometer (AAS) based on Association of Official Analytical Chemist AOAC [14].

\subsection{Amino Acids Analysis}

The amino acid profile in a known sample was determined using methods described by Sparkman et al. [16]. The known sample was dried to constant weight, defatted, hydrolyzed, evaporated in a rotary evaporator and then located into the technician Sequential Multisampling Amino Acid Analyser (TSM) Model DNA 0209. The TSM analyser is designed to separate and analyse free acidic, neutral and basic amino acids of the hydrolyzed and this lasted for 76 minutes.

\subsection{Statistical Analysis}

The descriptive statistics (mean and standard deviation) were conducted while statistical significance of differences $(P<0.05)$ were determined by analysis of variance (ANOVA) with SPSS version 10.0 [17].

\section{RESULTS}

\subsection{Proximate Composition in the Studied Fish Population}

In this section, the proximate composition of fishes in the two populations (wild, cultured) were explored in Fig. 1 and it was recorded that the proximate compositions measured were higher in cultured population compared to the Wild (Fig. 2). There was a statistical significant difference in the amount of crude protein across the two tested populations (Wild; $17.94 \pm 0.19$, Cultured; $21.06 \pm 0.51), t=-5.738, p$-value $=0.001$. Also, there exist a statistical correlation in the amount of Fibre across the two sampled populations (Wild; 1.19 \pm 0.06, Cultured; $1.80 \pm 0.16)$, $\mathrm{t}=$ $3.594, p$-value $=0.011$. Contrarily, Ash content in the two tested populations (Wild; 9.66 0.41, Cultured; $10.19 \pm 0.47, \mathrm{t}=-0.833, \mathrm{p}$-value $=0.424$ ) of fish species do not differ significantly. Furthermore, Crude fat content, Moisture content and Carbohydrate were significantly higher in cultured populations compared to Wild ( $p$-value < 0.05) (Fig. 1).

\subsection{Elemental Composition}

In this section, the elemental content such as Copper $(\mathrm{Cu})$, Lead $(\mathrm{Pb})$, Zinc $(\mathrm{Zn})$ in fishes in the study populations were explored. Fig. 2 depicts the distribution of elemental compositions across the two sampled populations. The maximum amount of copper (Cu), Lead (Pb), Manganese $(\mathrm{Mn})$ and Iron (Fe) were higher in Wild population than the cultured counterpart (Fig. 2). Similarly, the maximum amount of Iron (Fe), (Cd) and (Ni) observed in Wild population were higher than cultured population. Contrarily, the maximum content of Zinc $(\mathrm{Zn})$ found in cultured population (0.17) was higher than the Wild population $(0.00)$.

\subsection{Amino Acids Profile of the Wild and Cultured Clarias gariepinus}

The results also showed that there were high levels of amino acids in the cultured than in the wild fish populations (Table 1). Also, the descriptive statistics showed that there was no statistical significant difference in Lysine content across the two populations (Wild: $1.71 \pm 0.02$, cultured; $2.23 \pm 0.24), \mathrm{t}=-2.146, \mathrm{p}$-value $=$ 0.057 . Leucine content differ significantly across the two populations (Wild; $1.51 \pm 0.01$, Cultured; $2.73 \pm 0.31), \mathrm{t}=-3.896, \mathrm{p}$-value $=0.003$. Similarly, there was a statistical significant difference in Aspartic Acids content between the Wild $(1.83 \pm 0.04)$ and the Cultured population $(2.49 \pm 0.16), t=-4.136, p$-value $=0.002$. Further, each content of Isoleucine Acids, Glutamic Acids, Arginine Acids, Alanine Acids, Threonine Acids and Proline Acids differ significantly across Wild and cultured populations ( $p$-value < 0.05) (Table 1). 

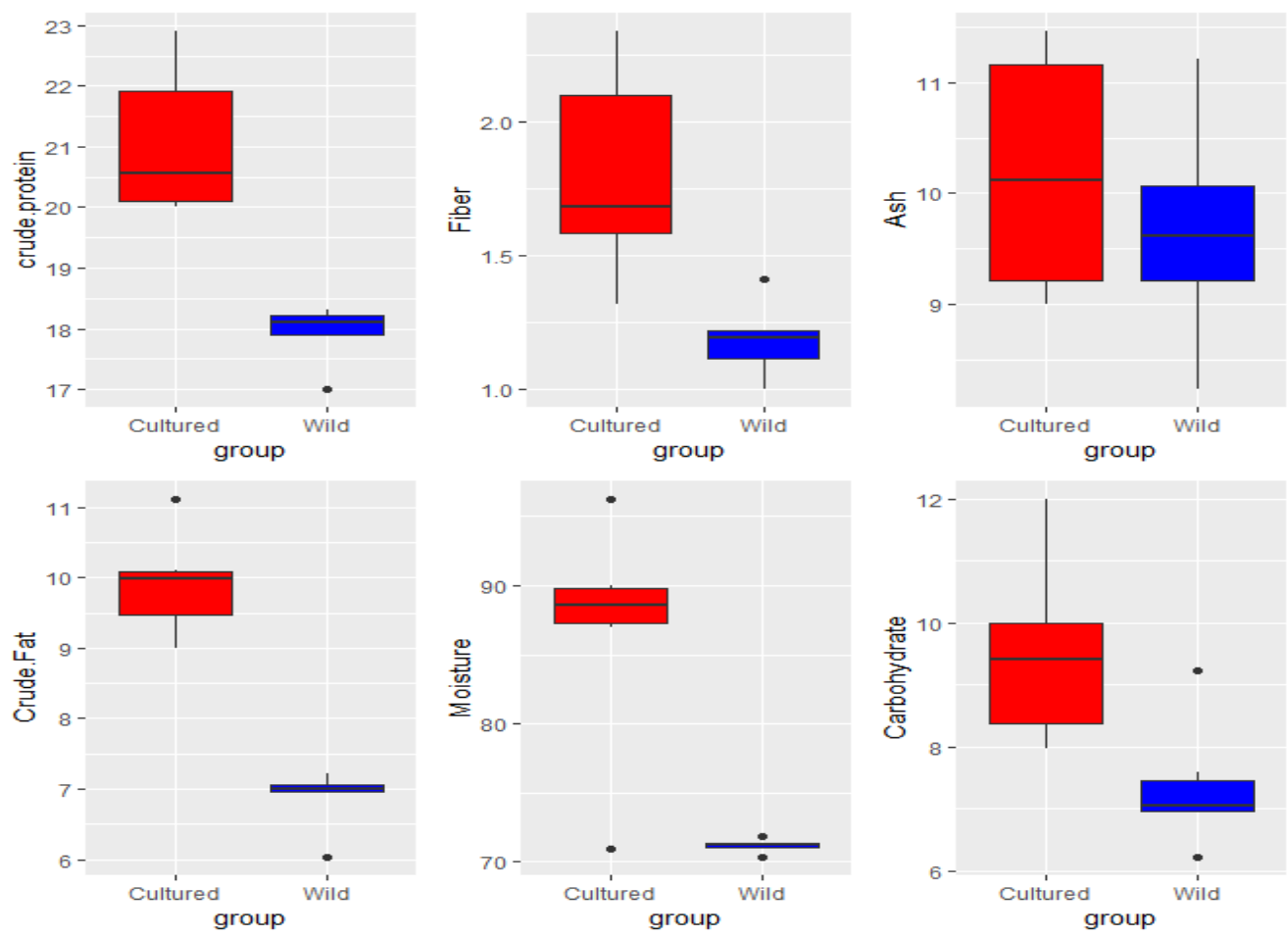

Fig. 1. Boxplot depicting the proximate composition of wild and cultured fish populations
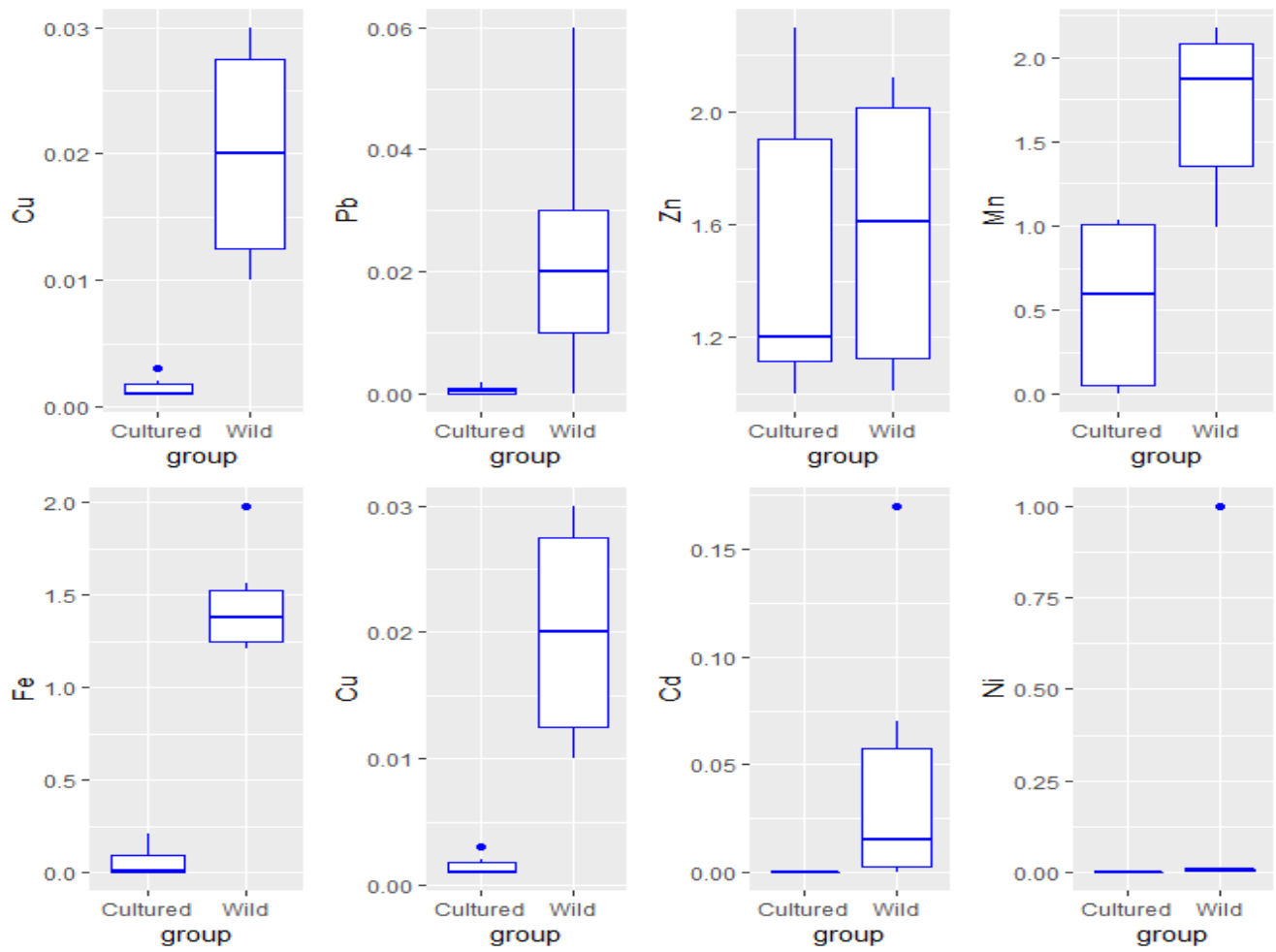

Fig. 2. Elemental/ mineral composition in cultured and wild populations of Clarias gariepinus 
Ayandiran et al.; ARRB, 36(2): 96-106, 2021; Article no.ARRB.51137

Table 1. Amino acids profile the sampled wild and cultured Clarias gariepinus

\begin{tabular}{|c|c|c|c|c|c|c|c|c|}
\hline \multirow[t]{3}{*}{ Amino acids profile } & \multicolumn{6}{|c|}{ Group } & \multirow[t]{3}{*}{ t- statistic } & \multirow[t]{3}{*}{ p-value } \\
\hline & \multicolumn{3}{|c|}{ Wild } & \multicolumn{3}{|c|}{ Cultured } & & \\
\hline & Min & Max & Mean \pm SE & Min & $\operatorname{Max}$ & Mean \pm SE & & \\
\hline Lysine & 1.65 & 1.77 & $1.71 \pm 0.02$ & 1.28 & 3.00 & $2.23 \pm 0.24$ & -2.146 & 0.057 \\
\hline Leucine & 1.47 & 1.55 & $1.51 \pm 0.01$ & 2.00 & 4.06 & $2.73 \pm 0.31$ & -3.896 & ${ }^{*} 0.003$ \\
\hline Valine & 0.56 & 0.99 & $0.80 \pm 0.08$ & 1.02 & 2.53 & $1.62 \pm 0.25$ & -3.141 & ${ }^{*} 0.01$ \\
\hline Aspartic Acids & 1.74 & 1.99 & $1.83 \pm 0.04$ & 2.11 & 3.01 & $2.49 \pm 0.16$ & -4.136 & ${ }^{*} 0.002$ \\
\hline Isoleucine Acids & 0.82 & 0.88 & $0.85 \pm 0.01$ & 1.10 & 1.88 & $1.37 \pm 0.13$ & -3.932 & ${ }^{*} 0.003$ \\
\hline Glutamic Acids & 2.38 & 3.01 & $2.8 \pm 0.09$ & 1.33 & 3.87 & $2.80 \pm 0.37$ & 0.009 & ${ }^{*} 0.003$ \\
\hline Arginine & 0.06 & 1.23 & $0.97 \pm 0.18$ & 0.92 & 2.39 & $1.66 \pm 0.23$ & -2.332 & ${ }^{*} 0.042$ \\
\hline Alanine & 1.04 & 1.21 & $1.09 \pm 0.03$ & 2.00 & 3.34 & $2.40 \pm 0.19$ & -6.543 & ${ }^{*} 0.001$ \\
\hline Threonine & 0.71 & 0.78 & $0.74 \pm 0.01$ & 0.51 & 2.39 & $1.58 \pm 0.26$ & -3.171 & ${ }^{*} 0.01$ \\
\hline Proline & 0.59 & 0.81 & $0.69 \pm 0.03$ & 1.23 & 2.22 & $1.84 \pm 0.45$ & -6.123 & ${ }^{*} 0.001$ \\
\hline
\end{tabular}

${ }^{*} p$-value $<0.05$ indicate significance 


\section{DISCUSSION}

\subsection{Proximate Analyzes}

The variation in the proximate composition among individuals of the same species is a common phenomenon in fish [18]. These variations were attributed to factors such as the geographical area in which the fish was caught, age, sex, size and the nature of feed used to feed the fish in the culture system. For all the proximate compositions measured, compositions were higher in cultured population compared to the Wild and this can be attributed to the fact that the cultured environment is well regulated and adequately controlled than their wild counterpart. The magnitude of the abuse done to the artificial pond is significantly low compared to the wild.

According to [14], proteins, lipids and moisture contents were the major constituents, when evaluating the nutritional value of fish. The nutritional elements showed varied values in all the sampled fish, with crude protein recording the highest values and fibre recording the lowest. This makes the fish an important candidate of good dietary protein sources and this is in agreement with the findings of $[19,20,21]$ who recorded higher protein content in fish. The crude protein content in fish from the wild were observed to be lower than those of the cultured and this could be attributed to varieties of the supplemental proteins being fed to the cultured populations. Generally in this study, both the Wild and cultured populace contain high protein content as observed in this study. The high tissue protein content may have resulted from high protein content of their diets and this same report was given by Osibona et al. [22].

The differences observed in the obtained protein values may be attributed to fish's consumption or absorption capability and conversion potentials of essential nutrients from their diet or their local environment into such biochemical attributes needed by the two fishes, this conformed to the findings of Adewoye and Omotoso [23]. Irrespective of the environment, moderate percentage of crude protein observed in this study could be attributed to the fact that Clarias gariepinus are good sources of pure protein and fish generally are good protein source. However, the nature and quality of nutrient in most animals is dependent upon their food types. This is why the feeding habit of individual fish species has great effect on their body's nutrient composition [24].
Based on the $5 \%$ fat composition criteria for discriminating lean fish from fatty species [25] it was apparent that both the wild and the cultured of the studied African catfish populace could be regarded as a fatty fish species. In this study, it was observed that the crude fat content was significantly higher in the cultured group than the wild. The higher percentage of lipid in cultured fish might be due to restricted movements in the confined environment, while the lower percentage of lipid recorded in the wild could be as a result of greater energy requirement in search for food and avoidance of predators due to unrestricted movement in the wild water. Egbal et al. [26] however argued that fat contents fluctuate considerably with age, feed and sexual cycle of fish.

Among the proximate composition examined, only the ash content is not significantly differ between the two groups. Nonetheless its composition is higher in the cultured groups than the wild ones. Therefore, both the wild and cultured groups are good sources of minerals such as calcium, magnesium, potassium, iron and zinc because ash is a measure of the mineral content of a food [27]. Ash is a measure of inorganic matter that has been burnt off.

Moisture content of the cultured group was significantly higher than that of wild group. This disparity may be due to size. Moisture of a given sample simply refers to the water content of that sample. Results obtained from the proximate analysis of both groups of the catfish showed that a fish sample of the cultured group has the highest percentage of moisture, $96.28 \%$ while a species of the wild group has the lowest moisture content, $70.34 \%$ (Table 1 ). In general the catfish studied had moisture ranging from $70.34 \%$ to $96.28 \%$ indicating that the percentage moisture in fish muscles was within the acceptable level $(60-80 \%)$ in all the samples. The percentage of water is also a good indicator of its relative content of energy, protein and lipid. There was a significant difference $(P=0.001)$ between the two groups.

The carbohydrate of all the samples in both wild and cultured samples had varied values intersecting, but however, the results obtained statistically from this work shown that the cultured group carbohydrate composition was higher significantly higher than that of the wild. Carbohydrate is a good source of instant energy that helps in the body's development and growth. The result in Table 1 shows that the various 
catfish are good sources of carbohydrate. The values of carbohydrate in both cultured and wild catfish were due to high moisture and high protein content, however, there was a significant difference $(P=0.0015)$ between their values.

Just like human, fish need an indigestible proportions of their diet to support the digestion. The crude fibres make sure that the food is better absorbed There was a statistical significant difference $(p=0.011)$ in the amount of Fibre across the two populations. The highest value was found in the cultured population with 2.34 and lowest in the wild population with 1.0 value (Table 1). This indicate that there is higher content of crude fibres in the feeds consumed by the cultured population compared to the natural foods available in the Oba reservoir for the wild populations.

\subsection{Elemental Composition}

The mineral composition in $\mathrm{mg} / 100 \mathrm{~g}$ of Clarias gariepinus is presented in Fig. 2. Interest in the metals, required formetabolic activities in organisms, lies in the narrow rangebetween their essentiality and toxicity [28]. Most of these Micro elements are equally important in trace amounts as observed, but they tend to become harmful when their concentrations in the tissues exceed the metabolic demands [22]. Minerals are important for vital body functions such as acid, base and water balance. The most abundant mineral in the wild fish samples was manganese which ranged between 0.99 to $2.18 \mathrm{mg} / 100 \mathrm{~g}$ sample. This is followed by zinc with range values of 1.01 to $2.12 \mathrm{mg} / 100 \mathrm{~g}$ while the least concentrated mineral was copper (0.01 to 0.03 $\mathrm{mg} / 100 \mathrm{~g}$ ). For their counterpart, the cultured population, the abundant mineral was zinc which ranged between 1.0 to $2.30 \mathrm{mg} / 100 \mathrm{~g}$ sample.

Among the metals examined, Nickel and Cadmium were totally undetectable in the cultured population and all the metals examined were significantly higher in the wild population compared to their cultured counterpart. It is interesting to note that harmful lead and cadmium were at the detectable range of AAS in all the wild population's samples. Cadmium was not detectable in the water but fairly high value observed in the African catfish. The standard permissible level of 0.05 to $5.5 \mathrm{mg} / \mathrm{kg}$ fish dry weight was reported for $\mathrm{Cd}$ [29]. None detection of $\mathrm{Cd}$ in the water body and high values of these metals in the fishes call for further research on the reservoir in order to determine the source(s) of these pollutants. It should be noted that $\mathrm{Ni}$ contamination is a real threat to the aquatic organisms due to their persistence nature and ability to bio-magnify in the aquatic food chain [30].

Metal concentrations in the tissue of fresh water fish varies due to differences in metal concentrations and chemical characteristics of water from which fish are sampled, their ecological needs; metabolism and feeding habits [31]. Several reports have shown that Iron $(\mathrm{Fe})$ is one of the most abundant metals in the earth crust [32]. The high value of $\mathrm{Fe}$ observed in this study compared to other metals may be due to increase in total dissolved iron in the Oba reservoir.

Copper is an essential element in the body and is required for different functions. It is a fundamental micronutrient to all forms of life in enzyme activity or random rearrangement of natural protein [33]. The high value obtained could be due to elevated metal binding protein synthesis. Similar observation of high value of copper in fishes attributed to elevated metal binding protein synthesis has also been reported [34]. African catfish is omnivorous and preys on small fish of other species. This could have led to high $\mathrm{Cu}$ levels in Catfish as compared to tilapia which feeds on phytoplankton. The $\mathrm{Cu}$ concentration levels recorded in muscles of the two populations were below the WHO recommended limit of $3.0 \mathrm{mg} / \mathrm{kg}$ in fish and fish products [35] and standard level of $20 \mathrm{mg} / \mathrm{kg}$ (dry weight) has reported by TFC [36]. However, there is no guideline on acceptable levels of $\mathrm{Cu}$ in fish suggested by European Economic Community or FAO/WHO [37]. The level of $\mathrm{Cu}$ in the evaluated fishes is not considerably high.

The main source of $\mathrm{Zn}$ pollution in aquatic environment is from fertilizers, sewage sludge, industrial wastes and mining [38]. Fish takes up $\mathrm{Zn}$ directly from water, especially via mucous and gills. The highest mean $\mathrm{Zn}$ concentration in African Catfish muscles was observed at the wild population $(1.58 \pm 0.213 \mathrm{mg} / \mathrm{kg})$ and the lowest at the cultured counterpart $(1.49 \pm 0.231$ $\mathrm{mg} / \mathrm{kg}$ ). The sources of $\mathrm{Zn}$ in this study may be attributed to usage of chemical fertilizers, sewage sludge and industrial wastes from the catchment. The maximum zinc level permitted for fish is $50 \mathrm{mg} / \mathrm{kg}$ according to Food Codex. However, Zn levels recorded during this study in the two African catfish population were below the $75 \mathrm{mg} / \mathrm{kg}$ recommended limit for $\mathrm{Zn}$ in fish and 
fish products [39]. Zinc is known to be involved in most metabolic path-ways in humans and zinc deficiency can lead to loss of appetite, growth retardation, skin changes and immunological abnormalities [40].

Lead $(\mathrm{Pb})$ is a non-essential element and higher concentrations in aquatic organisms may be due to discharge of industrial, sewage and agricultural wastes into aquatic environment [41]. Lead even at low concentration is known to be toxic and has no known function in biochemical process (Mishra et al., 2010). Wild population have the highest mean level of lead $(0.023 \pm$ $0.009 \mathrm{mg} / \mathrm{kg}$ ) in Catfish muscles and their values were significantly differ $(p<0.05)$ to the cultured population. In this study, the African Catfish from the wild had higher $\mathrm{Pb}$ levels compared to the cultured counterpart which could be attributed to their different feeding habits. $\mathrm{Pb}$ concentrations recorded in the two population during this study were lower than the WHO recommended limit of $2.0 \mathrm{mg} / \mathrm{kg}$ for $\mathrm{Pb}$ in fish and fish products [35]. The values of $\mathrm{Pb}$ were not high in the two populations of the African catfish. The standard level $\mathrm{Pb}$ was reported to be $0.5 \mathrm{mg} / \mathrm{kg}$ dry weight [42].

Manganese $(\mathrm{Mn})$ is one of the commonly found elements in the lithosphere. It is an essential micro nutrient and functions as a co-factor for many enzyme activities [43]. However, high Mn concentration interferes with central nervous system of invertebrates and hence a matter of concern as the consumption of Mn contaminated fish could result to Mn-related disorders in the consumers [44]. The Mn concentration levels in the two populations during the study did not exceed the WHO limit of $2.50 \mathrm{mg} / \mathrm{kg}$ for fish and fish products [45]. The $\mathrm{Mn}$ concentration in African Catfish was higher in wild population $(1.71 \pm 0.202 \mathrm{mg} / \mathrm{kg})$ and there was significant difference $(p>0.05)$ of manganese concentration levels in the two populations.

Iron is essential for metabolic reactions and the regulation of cell growth and differentiation; it is also an important constituent of haemoglobin [46]. The presence of Zinc in the fishes could mean that the fishes can play valuable roles in the management of diabetes, which result from insulin malfunction [47]. Lead (Pb), Copper (Cu) and Chromium $(\mathrm{Cr})$ have all been implicated as being toxic to the human body; therefore the continued consumption of catfish (Clarias gariepinus) from the Oba Reservoir, in Ogbomoso over a long period is likely to cause health hazards.

\subsection{Amino Acids Profile}

Amino acids are important in healing processes and the composition of amino acids in fish is similar to that in man, people can acquire essential amino acids in abundance and proper balance by eating fish. The essential amino acids cannot be manufactured in human bodies, but can be obtained from food. The present study indicated that the two species had all the essential amino acids. Deficiency in the essential amino acids may hinder healing recovery process (Mat et al., 1994). Leucine promotes the healing of bones, skin and muscle tissue. Isoleucine is necessary for haemoglobin formation, stabilizing and regulating blood sugar and energy. Glycine, which is one of the major components of human skin collagen, together with other essential amino acids such as alanine form a polypeptide that will promote regrowth and tissue healing [48].

Amongst essential amino acids, glutamic acids was present in the highest amounts in all analysed cultured population, followed by leusine, aspartic acidsand then alanine. Lysine is even higher as compared to the standard protein [29], which is severely restricted in cereals being the most important staple food in the world. A reduced supply of lysine in the diet may lead to mental and physical disorders as it is an essential precursor for the de novo synthesis ofglutamate, which is the prime neurotransmitter in themammalian central nervous system [49]. The highest amount of Glutamic acid being observed in all thecatfish species was in line with the study of Dezhabad et al. [50] and Kenari et al. [51]. All analysed freshwater fish species appeared to be anexcellent source of Glutamic acid which could enhancethe immune system. Both Glutamate and Glutamine playimportant roles in regulating gene expression, cell signalling, anti-oxidative responses and immunity [52].

As the amino acid composition of fish is similarto that in human beings, people can gain essential andnon-essential amino acids by consuming fish alongsidecereals to satisfy their body needs to maintain health [53]. In all the selected fish Lysine, Leucine, aspartic acids and glutamic acids were more abundant than the other amino acids. While Leucine promotes the healing of bones, skin and muscle tissues; Isoleucine is necessary for haemoglobin formation and regulation of blood sugar and energy; and Arginine is important for wound healing [54]. 
Since the quantity of theseamino acids in the selected fish were of sufficient level, the consumption of these fish could be beneficial insatisfying the body needs while treating metabolicdisorders and wound healing of the neighbouringcommunities of the study area and beyond.

With regard to their nutritional values, allselected fish contained all the essential amino acids thatwere needed by the human beings. It appeared that the cultured populationwas a richer source of total essential and non-essential amino acids as it had the highest respectiveamounts than the other species. The proportions ofessential to non-essential amino acid for the seven speciesof this study varied only slightly from 0.81 and 0.86 , these were either comparable to those of Dezhabad et al. [50] or greater than those of Kenari et al. [51].

\section{CONCLUSION}

From the scope of this research, it could be seen that the nutritional merits of the cultured catfish population is succinctly high compared to that of the wild population. As a result, proper monitoring of the Oba Reservoir should be ensured and continuous study of the reservoir should be enhanced in case of any additive effects of the detectable elements.

\subsection{Novelty Statement}

Consumption of African catfish is on the increase in Nigeria due to its socio-cultural and religious acceptability. The results of this research shows that both the wild and cultured catfish examined contained significant amounts of proteins thus redounding to the benefits of the society. This findings also indicated that the procured cultured population are more nutritious than their wild samples thus serving as an added advantage to its relative consumers. However, the results of this work will harness upcoming researches into the noted increase of some metals in the reservoir examined.

\section{COMPETING INTERESTS}

Authors have declared that no competing interests exist.

\section{REFERENCES}

1. Foran JA, Carpenter DO, Hamilton MC, Knuth BA, Schwager SJ. Risk based consumption advice for farmed Atlantic and wild pacific salmon contaminated with dioxins and dioxin-like compounds. Environmental Health Perspective. 2005;33:552-556.

2. Louka NF, Juhel Fazilleau, PV Loonis. A novel colorimetry analysis used to compare different drying fish processes. Food Control. 2004;15:327-334.

3. Kris - Etherton PM, William SH, Lawrence JA. Fish consumption, fish oil, Omega-3 fatty acids, and cardiovascular disease. Journal of the American Heart Association. 2002;106:2747-2757.

4. Osman AGM, Mekkawy IM, Verreth J. Frank F. Effects of lead nitrate on the activity of metabolic enzymes during early developmental stages of the African catfish, Clarias gariepinus. J. Fish Physiol. Biochem. 2006;10:9111-9118.

5. Waterman JJ. Composition and Quality of fish, Edinburgh, Torry Research Station; 2000.

6. Tyrrell L. Trace metal concentrations in various fish species landed at selected Irish Ports. Marine Environment and Health Series. 2003;20:1-19.

7. Haruna AB. Aquaculture in the tropics theory and practice, Kano Alhassan Publisher. 2003;432.

8. Malcolm RL. The chemical biology of fishes. Advance US edition published by Academic press Inc. New York, 1968,1977;2.

9. Chrysohoous C, Panagiotakos DB, Stefemedis C. Long term fish consumption benefits. Journal of Clinical Nutrition. 2007;55:13 19.

10. Connov W, The dietary intake of fish prevents atherosclerosis in diabetic women. Journal of Nutrition. 2004;80:2630.

11. Jacqueline SD, Nancy S, Carol AK, Kathi $\mathrm{N}$. The Role of Elements in Life Processes. 2011;19(2):34-48.

12. Johnson B. Fish and Fisher. Journal of Fish Biology. 2006;150:332 372.

13. Nelson JS. Fishes of the world. First edition. John Wiley and Sons Inc. London. 2006;40:45.

14. AOAC. Official methods of analysis. Association of Analytical Chemists, $18^{\text {th }}$ edition. Washington DC, USA; 2005

15. Kirk RS, Sawyer R. Fats and oil in: Pearson's composition and analysis of foods. $9^{\text {Th }}$ edition, Longman Group Limited, UK. 1991;708. 
16. Sparkman DH, Stein EH, Moore S. Automatic recording apparatus for use in Chromatography of amino acids. Anal. Chem. 1958;30:119

17. Duncan DB. Multiple range and multiple $F$ test. Biometrics. 1955;11:1-42.

18. Zenebe T, Ahigren G, Gustafsson B, Boberg M. Fatty acid and lipid content of Oreochromis niloticus L. in Ethiopian lakes. Dietary effects of phytoplankton. Ecol. Fresh Water Fish. 1998;7: 146-158.

19. Vlieg $P$. The proximate composition of New Zealand Marine fin fish and shel fish. FAO corporate document repository, New Zealand. Institute for Crop and Food Research;1988.

ISBN-477- 02520-X.

20. Fawole, et al. Mineral Composition in some selected fresh water fishes in Nigeria. J. Food Safety. 2007;(9):52-5.

21. Fawole OO, Yekeen TA, Adewoye SO, Ogundiran MA, Ajayi OE, Nwaiya MN. Nutritional qualities and trace metals concentration of six fish species from Oba Reservoir, Ogbomoso. Nigeria African Journal of Food Science. 2013;7(8):246252.

22. Osibona AO, Kusemiju K, Akande GR. Proximate composition and fatty acids profile of the African Catfish Clarias Gariepinus Acta Satech, In Press. 2006;3(1).

23. Adewoye SO, Omotosho JS, Nutrient composition of some freshwater fishes. Nigeria Bioscience Community. 1997;11:333-336.

24. Fagbenro OA, Adeparusi EO, Jimoh WA. Evaluation and nutrients quality of detoxified jackbean seeds cooked in distilled water or trona solution, as a substitute for soybean meal in Nile tilapia, Oreochromis niloticusdiets. Journal of Applied Aquaculture. 2007;19(2):83-100.

25. Ackman RG, Nutritional composition of fats in seafood. Prog. Food Nutrition Sci. 1989;13:161-241.

26. Egbal OA, Mohammed EA, Regiah AK, Hana MT. Asgad AM. Investigating the quality changes of raw and hot smoked Oreochromis niloticus and Clariaslazera. Hoffman LC, Prinsloo JR, Case NJ; 2010.

27. Oladipo IC, Bankole SO. Nutritional and microbial quality of fresh and dried Clariasgariepinus and Oreochromis niloticus. Int. J. Appl. Microbiol. Biotechnol. 2013;1:1-6.
28. Fatoki OS, Lujiz N. Ogunfowokan AO. Trace metals pollution in umtatma river. Water South Africa. 2002;28:83-89.

29. FAO. Protein quality evaluation. Report of the Joint FAO/WHO Expert Consultation; 2015.

30. Ubaid-ullah $\mathrm{M}$, Javed $\mathrm{M}$, Abdullah $\mathrm{S}$. Impact of waste disposal on the uptake and accumulation of heavy metals in the planktonic biomass of the river Ravi. Int. J. Agric. Biol. 2004;6:629-632.

31. Yilmaz $F$. The comparison of heavy metal concentrations ( $\mathrm{Cd}, \mathrm{Cu}, \mathrm{Mn}$ and $\mathrm{Zn})$ in tissues of three economically important fish (Anguilla Anguilla, Mugilcephalus and Oreochromis niloticus) inhabiting Koycegic Lake -Mugla (Turkey). Turkish Journal of Science and Technology. 2009;4:7-15.

32. Ibrahim SA, Tayel SI. Effect of heavy metals on gills of Tilapia zilliiinhabiting the River Nile water (Damietta branch) and ElRahawy drain. Egypt. J. Aquat. Biol. Fish. 2005;9:111-128.

33. Bower JJM. Environmental chemistry of the element. Academic Press Landon; 1979.

34. Yacoub AM, Study on some heavy metals accumulated in some organs of three River Nile fishes from Cairo and Kalubiagovernorates. Afr. J. Biol. Sci. 2007;3:9-21.

35. WHO. Guidelines for drinking Water Quality: Recommendations 3rd Eds. World Health Organization, Geneva. 2004; 516.

36. Turkish Food Codex. The communique on maximum limits of contaminants in foodstuffs. (Communique No: 2002/63); 2002.

37. Mol S, Ozden O, Oymak SA. Trace metal contents in fish species from Atatürk Dam Lake (Euphrates, Turkey). Turk. J. Fish. Aquat. Sci. 2010;10:209-213.

38. Bradi $\mathrm{BH}$. Heavy metals in the environment. Interface Science and Technology, ed. Hubbard A, Elsevier Academic Press: Neubrucke. 2005;6

39. FAO. Fisheries and aquaculture topics. Quality and Safety of fish and fish products. Topical Fact Sheets. In: FAO Fisheries and Aquaculture Department, Rome; 2003 - 2012.

40. Malakootian $\mathrm{M}, \quad$ Tahergorabi $\mathrm{M}$ Daneshpajooh $\mathrm{M}, \quad$ Amirtaheri $\mathrm{K}$. Determination of $\mathrm{Pb}, \mathrm{Cd}, \mathrm{Ni}$, and $\mathrm{Zn}$ concentrations in canned fish in Southern Iran. Sacha. J. Environ. Stud. 2011;1(1):94-100. 
41. Osman AGM, Kloas W. Water quality and heavy metal monitoring in water, sediments and tissues of the African catfish Clariasgariepinus (Burchell, 1822) from the River Nile, Egypt. Journal of Environmental Protection. 2010;1:389400.

42. FAO/WHO. List of maximum levels recommended for contaminants by the joint FAO/WHO Codex Alimentarius Commission. 2015;3:1-8

43. Suresh B, Steiner W, Rydlo M, Taraschewski $H$. Concentrations of 17 elements in Zebra mussel (Dreissenapolymorpha). Environmental Toxicology and Chemistry, 1999;18:25749.

44. Krishna PV, Rao KM, Swaruparani V, Rao DS. Heavy metal concentrations in Fish Mugilcephalusfrom Machilipatnam Coast and possible health risks to fish consumers. British Biotechnology Journal. 2014;4(2):126-135.

45. FAO. Compilation of legal limits for hazardous substances in fish and fishery products, Food and Agricultural Organization, Fishery circular. 1983;464:5100.

46. Oyeleye O. Export potentials of smoked fish trade in Nigeria. The Guardian 19(8916): 27, Guardian Newspaper Publication, Lagos, Nigeria; 2003

47. Wim V, Issabelle S, Karen DH Stefan. John VC. Consumer perception versus scientific evidence of farmed and wild fish: Exploratory insights for Belgium.
Aquaculture International. 2007;15:121136.

48. Witte MB, Thorton FJ, Tantry U, Barbul A. $\mathrm{L}$ Arginine supplementation enhances diabetic wound healing, involvement of the nitric oxide synthesis and arginase pathways. Metabolism. 2002;51(10):12691273.

49. Papes FJ, Surpili S, Langone F, Trigo JR, Arruda $P$. The essential amino acid lysine acts as precursor of glutamate in the mammalian central nervous system. FEBS Letters. 2001;488:34-38.

50. Dezhabad A, Dalirie MS, Rasool S, Toudar SR. Amino acid profile of kutum (Rutilusfrisii), $\quad$ silver carp (Hypophthalmicthysmolitrix) and rainbow trout (Oncorhynchusmykiss). Afr. J. Agr. Res. 2012;7(34):4845-4847.

51. Kenari AA, Regenstein JM, Hosseini SV, Rezaei M, Tahergorabi R, Nazari RM. Amino acid and fatty acid composition of cultured beluga (Husohuso) of different ages. J. Aquat. Food Prod. Technol. 2009;18(3):245-265.

52. Wu G. Functional amino acids in growth. Advanc. Nutr. 2010;1:31-37.

53. Osibona AO, Kusemiju K, Akande GR. Fatty acid composition and amino acid profile of two freshwater species, African Catfish (Clariasgariepinus) and Tilapia (Tilapia zillii). Afr. J. Food Agr.Nutr. Develop. 2009;9(1):608-621.

54. Williams JZ, Barbul A. Nutrition andwound healing. Crit. Care Nurs. Clin. North Am. 2012;24:179-200.

(c) 2021 Ayandiran et al.; This is an Open Access article distributed under the terms of the Creative Commons Attribution License (http://creativecommons.org/licenses/by/4.0), which permits unrestricted use, distribution, and reproduction in any medium, provided the original work is properly cited. 